\title{
LANGUAGE LEARNING AND TEACHING USING NEW TECHNOLOGIES
}

\author{
Budiakova Arina Sergeevna \\ преподаватель \\ Школа иностранных языков «BRITANNICA»
}

\begin{abstract}
How the new technologies can be used to assist the language learning and which innovative applications are helpful to meet the continuously increasing demands of learners is the focus of this study. New technologies including overhead projectors, interactive whiteboards, computers and wireless internet have opened up the classroom to the outside world. The teaching-learning process has to adapt to changing learning contexts. Technology provides a learner independent in language learning. Thus, technology enables the learner's efforts easier and faster. At present, there are several online services and some of them are free. It is possible that many more services will be available in future.
\end{abstract}

Key words: Language Learning, Educational Tools, Education Technology.

With the advent of new technologies such as mobile phones, tablets, learning context has changed from conventional to digital. Learners started adopting the use of new technology in their learning [5, p.33]. Different forms of technology have always been part of the teaching and learning environment. It is part of the teachers professional toolbox. It is among the resources that teachers use to help facilitate student learning [2, p.73]. The teaching-learning process has to adapt to changing learning contexts. Technology has entered into every field including the field of education. Students and teachers are equipped with the required skills for language learning. They also need to update their technical skills for handling the tools for the changing language learning demands, since these technology tools are the powerful instruments to deal with the continuously evolving learning needs.

Research findings in recent years provide evidence of the importance of encouraging student control over the learning process as a whole [1]. With the innovations in the field of technology and its applications, several services are available for learning and teaching. Out of those what are the technological tools available for language learning, how far are they potential and what are their effective uses and applications. 
A fundamental issue around the interaction between technology and education is the conditions under which technology can be effectively used in classrooms to improve student learning. Teachers need to be aware of the latest technological tools and which specific tool is suitable for which teaching-learning purpose. How to use technology depends on the learners, teachers, and the purpose of teaching. The effectiveness of the tool depends on a learner or teachers' choice its portability, affordability, multimedia effects, and availability. Some of the popular technological tools include a computer, cell phones, iPods, CDs, podcasts, etc. New initiatives are needed to promote the use of technology for research on CALL and for facilitating second language acquisition [2. p.74]. New initiatives are to be found and implemented for second language learning which is suitable for the local conditions and needs. There are now richer and more engaging pathways to learn than ever before, but this calls for us to engage with the new tools and gain a deeper understanding of their potential for enabling choice, creativity and selfdirection for learners.

It is necessary to maintain the sustained motivations of the learners through some new teaching-learning methodologies. Research to improve teaching-learning is a continuous process. In this process, innovatory methods are introduced [1]. How the new technologies can be used to assist the language learning and which innovative applications are helpful to meet the continuously increasing demands of learners is the focus of this study. New Technologies Technology has changed dramatically over recent decades. The increasing variety and accessibility of technology have expanded the toolbox and the opportunities teachers have to use technology.

To meet the teaching/learning requirements of growing demands, technology is changing continuously. Varieties of technological tools are continuously added for the process of teaching/ learning.

New technologies like overhead projectors, interactive whiteboards, laptop computers and wireless internet have opened up the classroom to the outside world. Using PowerPoint to present grammar, playing podcasts to practice listening skills, pulling texts off the world wide web to introduce reading skills and empowering students by giving them access to a wide range of web-based tools that allow them to publish work and engage with live audiences in real contexts.

New technologies are linking up the globe enabling the learners to access readily available data. These technologies are empowering both teachers and learners. Various technological tools and applications are extending the horizons of 
language skill development. Software Tools Software tools include: Video Conferencing, Blogs, Skype, Facebook, Podcasts, Youtube, Yahoo Groups, PowerPoint, Slideshare, Google Drive (Formerly Docs), Document archiving service, Video servers (Blip TV and YouTube), Digital audio and video recorders, Media Player, Windows Movie Mak, Twitter, Facebook. In India, social tools like Twitter, Facebook, Youtube, Skype and Whatsapp are quite popular. Google Drive, PowerPoint presentations, video conferencing, phone-in programs, video games, media player, search engines like Yahoo and Google are in vogue for academic and non-academic purposes. Audio Recorders Audio recorders such as talking tins, pegs or cards can be used to reinforce the learning of traditional rhymes or to record the singing of popular songs. Talking photo albums have been successfully used to create stories with an oral narrative. Text can be inserted along with the photos into each page of the album and the user can subsequently record a corresponding narration Recording gadgets also have a major role to play in assessment, where examples of oral work can be saved and revisited at a later time in order to show progression in learning. It is necessary to record the progress of learning of students to estimate the learning process for further practice. Video conferencing is a highly efficient way of inviting visitors into classrooms and for enabling learners to collaborate with each other at distance. Through this method, learners are exposed to native English speakers and for facilitating cultural exchanges. This resource can then easily be shared between several institutions [5, p.37].

These interactive sessions can be facilitated through the intervention of a teacher. Students are exposed to native language along with their cultural settings. This would enable the learners to understand the meanings easily. Language learning takes place in an atmosphere, which is conducive to learners. Learners are completely aware of what they are learning. Students can use video cameras to record their mouth movements to develop phonetic accuracy; recordings can subsequently be compared with standard models sourced from the internet [4, p.19]. Apart from having learning clues, these interactive videos are highly motivational. Students can follow the videos and improve their own pronunciation.

Each week students may have a different theme and get to share songs, pictures and quotations connected to the theme. Create an interactive place for students to interact with you and with each other outside the classroom. Moblogging is one of the newest technologies with potential application in language learning is „mobloggingee, an amalgam of mobile and weblogging. Blogs are a recent trend in language teaching. They provide opportunities for language creation (i.e., 
journaling) and collaborative activities. Moblogs offer the potential to expand these benefits by removing time and place boundaries and adding authentic and personal visual content [4, p.13].

Personal Digital Assistants (PDAs) PDAs are more often associated with m-learning than cell phones. PDAs offer numerous other uses, including Internet and wireless access, and therefore file-sharing between teachers and students and amongst students. Data is also easily backed up on personal computers. Further, at present, a standard feature of these devices is handwriting recognition [3, p.739]. Digital audio files (e.g., MP3s) provide high-quality sound in a compressed format. For example, A middle school in Nebraska, USA, is reported to have been using iPods to record speech samples for self and teacher assessment of English language learners. The iPod has also spawned a new form of media known as podcasting, a portmanteau which combines iPod and broadcasting. Podcasting is already widely utilized in language learning, both to access authentic content and to record it. Myriad subscriptions are available to English and other language learners.

Voice of America "Special English programs has also been made available via podcast. Discussion Technology has become a significant part of our life. The gadgets have become part and parcel of students ${ }^{\text {ee }}$ life, with its easy access and cheap availability of mobile phones made individuals more dependent with their complex communication needs in day to day life.

Technology has entered into almost every part of our life. Both learners and teachers are dependent on technology for every need including their communicational need. Students ${ }^{\text {ee }}$ dependency on technology should be steered towards language learning. Students feel highly attracted to new technologies with its game-like possibilities. How far a particular technology is useful in terms of suitability of - age, content, curriculum and technical considerations - depends on both teacherand learner. Mobile technologies are readily available to many Indian students because of their portability, cost-effective than a computer, availability, etc. The disadvantages of mobile phones are reduced screen sizes, limited audiovisual quality, virtual keyboarding and one-finger data entry, and limited power. Further, their availability can be limited. A computer is better than a mobile phone for handling various types of information such as visual, sound, and textual information, but the mobile phone is superior to a computer in portability. And some students do not have their own computer [3, p. 730]. Thus, the mobile phone and computer compensate for each other disadvantage. Depending on the 


\section{МОДЕРНИЗАЦИЯ СОВРЕМЕННОГО ОБРАЗОВАНИЯ: АНАЛИЗ ОПЫТА И ТЕНДЕНЦИЙ}

availability and suitability a learner should choose a particular technology. Young language learners need to be offered opportunities to practice target language in as many ways as possible.

Technology has the potential to provide learners with the opportunity to communicate with others, often native speakers of the language they are learning. Technology allows learners who would not normally have as many opportunities to use the language they are learning in productive ways to communicate with other speakers of the target language. To grab the attention of the learners, students should be provided with varied technological opportunities. This could be an interactive session with a native speaker who could be a subject expert. Or varieties of activities, drill exercises for spelling, vocabulary and grammar. A supportive school environment is important for successful technology integration for language learning. Teachers need access to a healthy human infrastructure and a functional and convenient technical infrastructure. Even though in recent years there is great progress in bringing computers and networks to schools, in many school teachers did not have easy access to either of the two infrastructures. Teachers should take an evolutionary rather

IRA-International Journal of Education \& Multidisciplinary Studies 20 than a revolutionary approach to change. It is likely that teachers will experience more success and less frustration if they take small but progressive steps toward change. Sometimes, teachers need to convince school management to get availability to the technology for language learning. Awareness regarding technology used for language learning is the responsibility of every teacher.

With the use of technology, learning has become more interesting and effective to the learners by making a clear change from teacher-centered learning to student-centred learning. It plays a vital role in addressing the needs of the learner. Technology provides a learner independent in language learning. Thus, technology enables learners' efforts easier and faster. The learner can be more focused on learning a specific language skill. Mobile learning is less structured than e-learning, but it complements e-learning perfectly. Though mobile learning is comparably less structured, it has innumerable advantages including portability and availability. Language learning using mobile phones is gaining prominence. At present, there are several online services and some of them are free. It is possible that many more services will be available in future. 


\section{References}

1. Emma, Segev. Mobile learning // Improve your English anytime, anywhere. - https://www.britishcouncil.org/voices-magazine/mobile-learningimprove-english-anytime-anywhere (24.09.2018)

2. Eady M. J. and Lockyer L., Tools for learning: technology and teaching strategies // Learning to teach in the primary school, Queensland university of technology. - 2019. - pp. 71-81.

3. Garrett N., Computer-assisted language learning trends and issues revisited: integrating innovation // The modern language journal. - 2009. - № 2. pp. 719-740.

4. Kondal B, Prasad Durga V., Developing language skills through mall among the professional students. - 2016. - pp.12-20.

5. Mc Loughlin C, Lee Mark J. W. Personalised and self-regulated learning in the web 2.0 era // International exemplars of innovative pedagogy using social software. -2010 . - pp. 28-43.

(C) A.S. Budiakova, 2021 